\title{
Complementarities between IT and Organizational Structure: The Role of Corporate Exploration and Exploitation
}

Ferdinand Mahr and Tobias Kretschmer

Discussion Paper 2010-3

May 2010

Munich School of Management

University of Munich

Fakultät für Betriebswirtschaft

Ludwig-Maximilians-Universität München

Online at http://epub.ub.uni-muenchen.de/ 


\title{
Complementarities between IT and Organizational Structure: The Role of Corporate Exploration and Exploitation
}

\author{
Ferdinand Mahr, Tobias Kretschmer \\ Institute for Communication Economics, Munich School of Management, LMU Munich \\ (f.mahr@lmu.de,t.kretschmer@lmu.de)
}

May 2010

\begin{abstract}
The decentralization of organizational decision authority has been shown to be complementary to Information Technology (IT) in prior research. We draw from the information processing view of organizations, the IT and de/centralization debate, and organizational learning theory to argue that IT payoffs can also be improved by greater centralization of decision authority, contingent on a firm's corporate learning type. We argue that an exploratory learning type is best pursued with a decentralized organization design, while an exploitative learning type requires a centralized organization design. We hypothesize that under corporate exploration, IT payoffs are enhanced through greater decentralization, whereas under corporate exploitation, returns to IT are improved by greater centralization. Our study uses a novel multi-source panel on the IT capital, the degree of de/centralization, and the performance of almost 260 German manufacturing firms. We estimate production functions to assess the contribution of combining IT with de/centralization to firmlevel productivity under different corporate learning types. Our results strongly support our hypotheses and hold up to a variety of robustness tests.
\end{abstract}

Keywords: information technology; decentralization and centralization; exploration and exploitation; firm performance; complementarities

\section{Acknowledgments}

We are grateful to Chiara Criscuolo, Mirko Draca, Bo Eriksen, Luis Garicano, Georg von Graevenitz, Karin Hoisl, Mariana Rösner, Raffaela Sadun, Fiona Scott-Morton, Hans Eibe Sørensen, and Nils Stieglitz for helpful comments. We would also like to thank reviewers, audiences and discussants at the Fifth biannual Conference on The Economics of the Software and Internet Industries (Toulouse), the DRUID Summer Conference 2009 (Copenhagen), the 7th ZEW Conference on the Economics of Information and Communication Technologies (Mannheim), the 2009 Academy of Management Annual Meeting (Chicago), the Strategic Management Society $29^{\text {th }}$ Annual International Conference (Washington, D.C.), and seminar participants at the University of Southern Denmark as well as the University of Munich. Further, we thank the interviewer team Luisa Feigenspan, Sebastian Jacobs, Stefan Jelinek, Stephanie Leopold, Werner Skalla, Dorothee Stadler and Veronika Triphan. This research has been generously supported by Deutsche Telekom Foundation. Remaining errors are the authors'. 


\section{Introduction}

Information technology (IT) has been a central issue in the research on firm performance and organization design for more than 50 years (Zammuto et al. 2007). Early research on the relationship between IT and firm performance uncovered a "productivity paradox" (Brynjolfsson 1993, Solow 1987). Subsequent studies found positive returns to IT (Anderson et al. 2006, Bharadwaj et al. 1999, Dewan and Kraemer 2000, Mukhopadhyay et al. 1997), but also a substantial variation in the IT payoffs across firms (Brynjolfsson 1995, Loveman 1994). Further work arrived at the consensus that the returns to IT depend on the presence of complementary organizational factors (Aral and Weill 2007, Bertschek and Kaiser 2004, Bresnahan et al. 2002, Brynjolfsson et al. 2002, Sabherwal et al. 2006). Particularly, there is evidence that IT returns are enhanced by greater decentralization of organizational decision authority (Bresnahan et al. 2002, Brynjolfsson et al. 2002, Hitt and Brynjolfsson 1997). We build on and extend this line of research by arguing that IT can also be complementary to greater centralization, contingent on the corporate learning type pursued by a firm.

We draw on the information processing view of organizations to argue that IT reduces organizational information processing costs and enhances information processing quality (Anand and Mendelson 1997, Brynjolfsson and Mendelson 1993, Galbraith 1973, 1974, 1977, Tushman and Nadler 1978). Particularly, IT enhances horizontal and vertical information processing, which are needed to support both decentralized and centralized organizational designs (Dewett and Jones 2001, Huber 1990, Pinsonneault and Kraemer 1997). Thus, IT may complement either greater decentralization or greater centralization. Indeed, this view has been supported by earlier (conceptual and case- based) research (Bolton and Dewatripont 1994, Dewett and Jones 2001, Galbraith 1973, 1977, George and King 1991, Gurbaxani and Whang 1991, Leavitt and Whisler 1958, Huber 1990, Nault 1998).

This suggests that third factors may determine the direction of complementarities between IT and de/centralization (Robey 1977). To explore this issue, we build on organizational learning theory which contends that firms must emphasize one of two learning types, exploration or exploitation (March 1991, Gupta et al. 2006). At the corporate level, exploration refers to the ongoing search for new 
products and markets, while exploitation means the continuous improvement of existing product market domains (Auh and Mengue 2005, He and Wong 2004, Lubatkin et al. 2006). Many scholars argue that both learning types are best pursued with different organization designs (Ancona et al. 2001, Benner and Tushman 2003; Brown and Eisenhardt 1998, Burns and Stalker 1961, Duncan 1976, Roberts 2007, Lewin et al. 1999, Tushman and O’Reilly 1996). Specifically, exploration requires considerable employee autonomy for constant experimentation and adaptation, so that a decentralized organization design is most appropriate. Conversely, exploitation succeeds by minimizing variation and maximizing efficiency and control, calling for a centralized organization (Benner and Tushman 2003).

Taking these interdependencies into account, we argue that the corporate learning type defines the direction of complementarities between IT and de/centralization in any particular firm. Specifically, we hypothesize that IT and greater decentralization are complementary for explorers, while for exploiters IT and centralization are complementary.

We use a unique and detailed multi-source panel dataset on computers, organization design, and corporate learning type of over 250 German manufacturing firms to test our hypotheses. Our results support prior findings that IT positively affects firm performance and that the effect is moderated by the degree of de/centralization. However, in support of our hypotheses, we find no single best combination of IT and de/centralization. Instead, IT is complementary to decentralization in firms with an exploratory learning type, while it is complementary to centralization for exploiters. A number of checks demonstrate that our results are robust to alternative specifications and measures.

Our study contributes to several research fields. First, we contribute to the IT returns literature by opening the black box of the organizational factors increasing a firm's ability to generate positive returns from IT. Specifically, rather than simply testing for complementarities we identify a contingency factor affecting these complementarities. Second, ours is the first large sample empirical study finding evidence for complementarities between IT and centralization, thus contributing to the long-lasting IT and de/centralization debate. Third, we contribute to the discussion on how IT supports different types of organizational learning (Kane and Alavi 2007) and product market strategies (Chari et al. 2008). 
Our research has important managerial implications. The notion that returns to IT depend on organizational complements is confirmed. More importantly, our findings imply that there is no sinlge "best practice" of how to best utilize IT through organization design. Instead, our findings emphasize the general purpose properties of IT, specifically its ability to positively affect firm performance in different organizational settings (Bresnahan and Trajtenberg 1995, Brynjolfsson and Hitt 2000, David 1990, David and Wright 1999). A central implication is therefore that managers have to align their IT and their organizational structure in combination with their product market and learning strategies.

The remainder of this paper is organized as follows. In the next section, we develop our hypotheses in the context of relevant previous research. In $\S 3$, we describe our research design, data and variables. The results of our analysis are provided in $\S 4$. We conclude by discussing the implications of this research for managers and researchers in $§ 5$.

\section{Prior Literature and Hypothesis Development}

\subsection{Information technology and firm performance}

Most early research on the relationship between IT and productivity found no or negative relationships at the economy or sector levels (Brynjolfsson 1993, Roach 1987, Solow 1987). Beginning in the 1990s however, studies with improved data and methodology found positive returns at the economy and firm level (Anderson et al. 2006, Bharadwaj et al. 1999, Brynjolfsson and Yang 1996, Dewan and Kraemer 2000, Mukhopadhyay et al. 1997).

As firm level returns to IT vary substantially across firms (Brynjolfsson 1995, Loveman 1994), the emerging consensus is that returns to IT investments are contingent on the presence of complementary factors (Aral and Weill 2007, Bertschek and Kaiser 2004, Bharadwaj 2000, Chari et al. 2008, Clemons and Row 1991, Mata et al. 1995; Powell \& Dent-Micaleff 1997, Sabherwal et al. 2006, Weill and Aral 2006). Particularly, there is solid evidence for complementarities between IT and the decentralization of organizational decision authority (Bresnahan et al. 2002, Brynjolfsson et al. 2002, Hitt and Brynjolfsson 1997). Existing studies find that the contribution of IT to firm performance is increased by complementary investments in the dispersion of decision rights and in HRM practices that endow the 
employees that are given more decision rights with the necessary skills and incentives to make high quality decisions (Bresnahan et al. 2002; Brynjolfsson et al. 2002, Hitt and Brynjolfsson, 1997). These studies were the first to econometrically address the IT and centralization/decentralization debate (George and King 1991, Robey 1977) using large samples and robust econometric methods.

\subsection{The information processing view of organizations and IT}

Organizations have been described as information processors (Galbraith 1973, 1974, 1977, Hayek 1945, Tushman and Nadler 1978). Organization design determines who coordinates a firm's specialized and interdependent subunits by defining how the information required for coordinating subunits is processed (Galbraith 1974, Tushman and Nadler 1978).

Coordination occurs through two alternative prototypical organization designs. First, centralized coordination is achieved through vertical information processing. Information from subunits is referred upward in the hierarchy to a central decision maker who processes the information, makes decisions, disseminates instructions downward to the subunits, and monitors their implementation. Second, decentralized coordination is attained through horizontal information processing. Autonomous subunits communicate directly and decide on activities and coordination without direction of superior levels (Aoki 1986, Galbraith 1974).

Both organization designs have relative strengths and weaknesses. Central decision makers typically lack some of the tacit local information on the subtasks requiring a "feel", "judgement", or "experience", for example regarding customer requirements (Anand and Mendelson 1997, Aoki 1986, Gurbaxani and Whang 1991, Leavitt and Whisler 1958). Further, under centralization, central decision makers can suffer from information overload, reducing decision speed and quality (Bolton and Dewatripont 1994, Galbraith 1974, Leavitt and Whisler 1958). In contrast, autonomous subunits lack a global view of all subtasks and the requisite incentive structure, which reduces their ability to coordinate in the firm's interest (Aoki 1986). Further, as decentralized coordination requires more communication than centralized coordination, it is considered more costly (Bolton and Dewatripont 1994, Radner 1993, Wyner and Malone 1996). 
IT increases the speed, quantity, and quality of information that can be transferred vertically and horizontally between organizational units (Dewett and Jones 2001, Huber 1990) as well as the information processing capabilities of organizational units (Galbraith 1974, Leavitt and Whisler 1958). Thus, IT is interlinked with organization design which determines how information is processed (Anand and Mendelson 1997, Brynjolfsson and Hitt 2000, Brynjolfsson and Mendelson 1993).

\subsection{Information technology, decentralization, and centralization}

IT can support a decentralized organization design by facilitating the horizontal information flow among subunits and endowing them with information from above, for example through groupware or database software. Increased processing power, e.g. through group decision systems, helps subunits handle the increased amount and complexity of horizontal and vertical information. Thus, subunits obtain a more global view, resulting in better decisions based on both local and global information (Anand and Mendelson 1997, Brynjolfsson 1994, Brynjolfsson and Mendelson 1993, Dewett and Jones 2001, Hitt and Brynjolfsson 1997, Huber 1990, Pinsonneault and Kraemer 1997, Robey 1977).

However, IT can also support centralized organization designs by allowing the movement of typically hard to transfer local information from subunits upward to central decision makers, for example through executive information systems. Higher processing power allows central decision makers to handle this additional information, e.g. through decision support or expert systems (Bolton and Dewtripont 1994, Brynjolfsson et al. 1994, Dewett and Jones 2001, Galbraith 1974, Gurbaxani and Whang 1991, Huber 1990, Leavitt and Whisler 1958, Nault 1998, Pinsonneault and Kraemer 1997, Robey 1977). Further, IT facilitates the dissemination of instructions and their subsequent control (Brynjolfsson et al. 1994, Gurbaxani and Whang 1991, Pinsonneault and Kraemer 1997).

Some authors argue that IT benefits decentralization more because it only partly reduces the relative disadvantages of centralized organization designs. Some residual tacit local information will stay nontransferable and not become available to central decision makers. At the same time, the local information that is made transferable and referred upward would overburden central decision makers as IT can increase human information processing power only moderately (Anand and Mendelson 1993, 
Brynjolfsson and Mendelson 1993, Daft and Lengel 1984, Hitt and Brynjolfsson 1997). Conversely, recent research maintains that humans are able to "compensatory adapt" to the differences between face-to-face and electronic communication (Kock 2004) as it is not the medium which determines the "richness" of communication but rather the social process surrounding its use. Even electronic media allow for rich communication including tacit knowledge (Lee 1994, Markus 1994, Ngwenyama and Lee 1997). Further, present-day IT systems such as enterprise resource planning, decision support and expert systems support decision makers in analyzing voluminous and complex information (Chari et al. 2007, Shim et al. 2002).

In summary, IT can enhance the value of decentralized and centralized organization designs by facilitating information processing. Therefore, if IT can be profitably combined with either design, unobserved third factors may determine which combination fits a particular firm best (George and King 1991, Huber 1990, Robey 1997). Studies finding that IT payoffs are enhanced through decentralization show one, but not necessarily the only fruitful combination of IT and organization design (Bresnahan et al. 2002; Brynjolfsson et al. 2002, Hitt and Brynjolfsson, 1997). Taking into account contingencies gives a more nuanced picture of the two-way complementarities between IT and organization design.

\subsection{The role of organizational learning}

One important contingency factor to be considered is the mode by which a firm develops, i.e. how they learn over time. March (1991) contends that firms have to choose between two fundamentally different types of organizational learning, exploration and exploitation. At the corporate level, exploration refers to permanent search for new products and markets, while exploitation refers to ongoing improvement of existing product market domains (Auh and Mengue 2005, He and Wong 2004, Lubatkin et al. 2006). The distinction between exploration and exploitation is used in strategy (He \& Wong 2004, Uotila et al. 2009, Ghemawat \& Ricart I Costa, 1993), organization theory (Holmqvist 2004), technology and innovation management (Benner \& Tushman 2003), and marketing (Kyriakopoulos \& Moorman 2004).

It is argued that exploration and exploitation require fundamentally different organizations designs, because of the distinct activities associated with them (Ancona et al. 2001, Benner and Tushman 2003; 
Brown and Eisenhardt 1998, Burns and Stalker 1961, Duncan 1976, Roberts 2007, Lewin et al. 1999, Tushman and O’Reilly 1996). Exploration draws on adaptability, flexibility, variation, and radical innovation, while exploitation implies alignment, efficiency, refinement, and incremental innovation (Adler et al., 1999; Gibson \& Birkinshaw, 2004; March, 1991; O’Reilly \& Tushman, 1996, Roberts 2007).

For corporate level exploration, firms must allow specialized subunits on lower hierarchical levels to constantly look for new opportunities and generate ideas. Subsequently, to innovate, the subunits must experiment with the ideas in direct communication with other subunits without delay through seeking information or permission from above. Many of these activities are highly judgment-related and creative and involve tacit local information. Central decision makers lack the local information and the processing power and speed to meaningfully coordinate such activities. Further, centralization would restrict the creativity of employees crucial for exploration. Thus, decentralized coordination is best suited to connect these activities to benefit the firm's overall goals, the exploration of new products and markets (Benner and Tushman 2003, Galbraith 1974, Roberts 2007, Stieglitz and Heine 2007).

Corporate level exploitation requires subunits at lower hierarchical levels to focus on efficient execution and incremental improvement of the existing agenda. Timely and efficient execution is strictly controlled, trial and error are discouraged. Further rationalization requires innovation, but the search for incremental improvements is restricted to the current agenda, so that even the development and implementation of process innovations can be formalized and disciplined. Decentralized subunits would lack the overall perspective to achieve such a streamlining of all subtasks, and horizontal information processing would be very costly. Consequently, centralized coordination works best to achieve corporate exploitation (Benner and Tushman, 2003; Roberts, 2007; Stieglitz and Heine, 2007).

The notion that firms with an exploratory learning type require a decentralized organization design while firms with an exploitative learning type require a centralized organization is supported by prior work (Ancona et al. 2001, Burns and Stalker 1961, Duncan 1976, Lewine et al. 1999, Miles and Snow 1978, Porter 1985). Firms with an exploratory learning type which requires decentralization therefore benefit from IT if they use it to support decentralization. In turn, firms with an exploitative learning type that requires centralization benefit from IT if it is used to enhance centralization. 


\subsection{Hypotheses}

As our analysis is at the corporate level, we use "exploration" and "exploitation" to denote corporatelevel activities. We draw on the information processing view of organizations and the IT and de/centralization debate. Through its capability to facilitate horizontal and vertical information processing, IT can enhance both greater decentralization and centralization. Further, increased IT use may require a corresponding change in the degree of (de-)centralization to exploit the potential of IT. We use organizational learning theory to argue that different corporate learning types require different organization designs. Exploration demands decentralization, exploitation calls for centralization. Consequently, a firm's learning type will determine the direction of the (two-way) complementarities between IT and de/centralization. ${ }^{1}$

Exploration requires decentralization. Thus, under exploration, IT's potential through facilitating information processing is facilitated through greater levels of decentralization.

HYPOTHESIS 1. Under exploration, the impact of information technology on firm performance will be greater for firms with greater levels of decentralization.

Conversely, exploitation requires centralization. Thus, under exploitation, IT's potentials for performance gains through facilitating information processing are realized through centralization.

HYPOTHESIS 2. Under exploitation, the impact of information technology on firm performance will be greater for firms with greater levels of centralization.

\section{Empirical approach}

\subsection{Empirical models}

In line with prior studies on the returns to IT and combinations of IT and organization design, we use a production function approach to test our hypotheses (Bresnahan et al. 2002, Brynjolfsson and Hitt 1996, Dewan and Min 1997, Dewan et al. 2007). We propose a standard Cobb-Douglas production

\footnotetext{
1 Note that we do not propose three-way complementarities between IT, decentralization and exploration or between IT, centralization and exploitation. Instead, we test for the existence of two-complementarities between IT and decentralization and IT and centralization. The learning type is not a third complement, but a contingency factor determining the direction of the two-way complementarities between IT and organization design. Hypotheses 1 and 2 thus have to be tested separately.
} 
function, specified in log-linear form as shown in model 1 below. Here, for firm $j$ at time $t, V A=$ value added is explained by $P C=$ number of computers, ${ }^{2} C=$ non-IT capital, $L=$ labor, and $D E C=$ the degree of decentralization. ${ }^{3}$ In line with existing studies we capture complementarities between computers and decentralization by means of a moderation effects model, i.e. an interaction term of $P C$ and $D E C$ (Bloom et al. 2007, Bresnahan et al. 2002, Brynjolfsson et al. 2002, Chari et al. 2008, Colombo et al. 2006, Crespi et al. 2006). $\mathrm{X}_{\mathrm{jt}}^{\mathrm{i}}$ is a vector of control variables described below and $\varepsilon_{\mathrm{jt}}$ an error term clustered by firm and Huber-White robust to heteroskedasticity and autocorrelation of unknown form.

$$
\operatorname{lnVA}_{j t}=\beta_{0}+\beta_{1} \operatorname{lnPC}_{j t}+\beta_{2} \operatorname{lnC}_{j t}+\beta_{3} \operatorname{lnL}{ }_{j t}+\beta_{4} D C_{j t}+\beta_{5}\left(\operatorname{lnPC}_{j t} \times D E C_{j t}\right)+\sum_{i} X_{j t}^{i}+\varepsilon_{j t}
$$

The slope coefficients $\beta_{1}$ to $\beta_{5}$ represent output elasticities for the inputs computers, non-IT-capital, labor, decentralization, and the interaction of computers and decentralization, i.e. the percent change in output for a one percent change in the quantity of the input when all other inputs are held constant. ${ }^{4}$

Our hypotheses concern the interaction effect, i.e. the joint effect of computers and decentralization on firm performance. If $\beta_{5}$ is significantly greater than zero, the effect of PC on VA depends on the level of DEC and vice versa, so that PC and DEC are complementary.

To test if the complementarities between computers and decentralization are contingent on a firm's learning type, we use subgroup analysis, a common approach in contingency research (Venkatraman 1989). Specifically, we analyze if the coefficient for $P C \times D E C$ for the explorer subgroup is different from the corresponding one for exploiters. Thus, we run model 1 separately for explorers and exploiters.

\footnotetext{
2 Our measure of IT is the number of computers in a firm. While this has some shortcomings vis-à-vis the use of specific software, it also has a number of advantages. We outline some of them in our data section.

${ }^{3}$ A criticism of this approach is that there may exist unobserved third factors like for instance managerial decisions which could explain the covariation of PC, DEC, and VA alternative to complementarities (Athey and Stern 2003). Hence the evidence presented here must "be considered suggestive conditional correlations rather than causal" (Bloom et al. 2007: 17).

${ }^{4} \mathrm{~A}$ different specification could use lagged input factors to account for the possibility that computers require an adjustment lag to fully affect firm performance. We do not consider lags in our main analysis because capital already includes effects of prior spending and including lagged inputs significantly reduces sample size (Brynjolfsson and Hitt 1995). We use lagged inputs as a robustness test.
} 
We expect $\beta_{5}$ to be positive and significant for explorers, indicating complementarities between computers and decentralization. As centralization is the inverse of decentralization, for exploiters $\beta_{5}$ would be negative and significant in case of complementarities between computers and centralization. ${ }^{5}$

\subsection{Data}

To avoid common method bias, we constructed our dataset on German manufacturing firms from three independent sources (Podsakoff et al. 2003): (1) a panel of the number of computers and firm characteristics over the period 2000-2008, (2) a panel of further production function inputs and output from 2000-2008, and (3) a 2008 cross-section of organization design and corporate learning type.

We obtained measures of computers and labor from Harte-Hanks' CI Technology Database (CITDB)6, which has been used in prior studies on the use and impact of IT (Bresnahan et al. 2002, Brynjolfsson et al. 2002, Dewan et al. 2007, Hitt and Brynjolfsson 1997, Kretschmer 2004, Forman 2005). Harte-Hanks, a market intelligence firm, conducts annual telephone surveys to take stock of specific IT types used by individual sites (establishments) of more than 10,000 German firms. As data are provided at the establishment level we aggregate to the firm level or extrapolate firm level measures if required. The firms in CITDB are largely representative for the population of German firms with over 100 employees.

Where possible, we derived the remaining quantitative data for our estimations from Bureau Van Dijk's ORBIS database which provides balance sheets and profit and loss statements from annual company reports. We also used ORBIS to assign every firm to an industry.

All German firms with at least one manufacturing establishment and covered by CITDB and ORBIS formed the pool of 600 potential respondents to a survey on the degree of de/centralization, HRM practices, and corporate learning type. We focused on the manufacturing industry to avoid issues with interpreting the output of service firms in production function estimations and to be able to use a single questionnaire. We surveyed production managers or similar roles, because they are typically in upper

\footnotetext{
5 To test if $\beta_{5}$ significantly differs between the subgroups, we employ a Chow test. To do this, we interact $P C \times D E C$ (and all other independent variables) with the dummy variable XPLOIT. XPLOIT indicates if a firm pursues an exploitative (XPLOIT=1) or an exploratory learning type $(X P L O I T=0)$. In addition to the three-way interaction $(P C \times D E C) \times X P L O I T$, this model includes the three linear terms $P C, D E C$, and $X P L O I T$ and the three possible two-way interaction terms composed of these variables $P C \times D E C$, $\mathrm{PC} \times X P L O I T$, and DEC $\times X P L O I T$ (Aiken and West 1991, Jaccard and Turrisi 2003). The significance test associated with $(P C \times D E C) \times X P L O I T$ is thus a test of the significance of the two groups having different slopes for $P C \times D E C$.

${ }^{6}$ Previously, this was the Computer Intelligence InfoCorp (CII) database.
} 
middle management and have insights on both the degree of de/centralization at lower hierarchical levels as well as more high-ranking ones on the corporate learning type. Through the narrow set of potential informants we hold single informant bias relatively constant. The surveyed establishments employed on average 70.0 percent of the firm's total employees, indicating that our measures are largely representative of the entire firms. Six research analysts conducted 259 telephone interviews in March 2008, a response rate of 43.2 percent.

Organizational structures and product market strategies are subject to inertial forces and tend to persist over time (Hannan and Freeman 1984, Miller and Friesen 1984). We thus assume that organization design and corporate learning type have only changed marginally in the years before our survey, other than outputs, computers, and the remaining inputs. The different adjustment speeds let us match 2000-2008 panels on output, computers and other inputs with a snapshot of organization design and learning type at the end of the panel period, in line with other studies (Bresnahan et al. 2002, Brynjolfsson et al. 2002, Bloom and Van Reenen 2007). Further, we asked survey respondents about the firm's corporate learning type in the five years before the survey to mitigate problems concerning the learning type. Potential problems concerning organization design are reduced by the fact that an alternative interpretation of our organization design measure would not materially affect the interpretation of our results. Instead of interpreting the measure as an indicator of the organization design in the years before the survey, it can be seen as an indicator of the direction of the organizational change that took place in the years before the survey (Bresnahan et al. 2002). This would not change the interpretation of results. For example, finding that greater computer investments in 2006 and greater decentralization in 2008 are associated with better performance in 2006-2008 could indicate that computers induced decentralization, which then allowed the firm to better exploit its IT potential.

After removing observations with missing data we are left with a final sample of 182 firms, with each firm contributing at least one of 572 observations used in our analysis. The firms do not significantly differ from all other German manufacturing firms included in CITDB and ORBIS and from nonrespondents in the number of firm employees, value added, total assets, and the number of computers. 


\subsection{Variables}

\subsubsection{Production function output and inputs}

The number of computers for each firm was obtained from CITDB. We aggregate from the establishment to the firm level. Where CITDB does not cover every establishment of a firm, we extrapolate firm level values by calculating the number of computers per employee for the covered establishments and multiplying this by the number of firm employees. On average, the establishments covered by CITDB employ 82.3 percent of total firm employees, indicating that our measure is largely representative of the whole firms.

While our IT measure, the number of computers in a firm, does not include other IT types like peripherals, interconnecting technologies, and software, it suits our purposes well. To test our hypotheses, we need to proxy for the extent to which the IT in a firm can facilitate both vertical and horizontal information processing. Computers are the interface that give employees at all levels access to a firm's IT infrastructure including peripherals, interconnecting technologies, and software. For example, only computers give employees at both lower and higher hierarchical levels access to software like executive information, decision support, expert, and enterprise resource planning systems. Thus, as computers enable employees to feed in, process, and read out information using a firm's IT infrastructure, the number of computers in a firm is a good proxy for the extent to which the vertical and horizontal information flow between employees is enabled by IT. In a firm with many computers, both vertical and horizontal information processing are facilitated. In contrast, with only few computers in place, a significant amount of vertical or horizontal communication takes place via alternative media that have disadvantages with regards to communication speed, quality, and quantity.

Value added (VA) was calculated as sales less material costs. Sales and material costs were obtained directly from ORBIS.

Non-IT capital (C) was computed as tangible fixed assets less IT capital. Tangible fixed assets were obtained directly from ORBIS, while IT capital was computed as follows. Annual average prices for desktop computers and for notebook computers were obtained from market reports by GfK Group. Specifically, we obtained average prices for every year from 2005 to 2008 and extrapolated the prices 
for 2000 to 2004. The average shares of desktop and notebook computers in the final sample were available in CITDB. $^{7}$ IT capital was then computed as (desktops $\times$ average desktop price)+(notebooks $\times$ average notebook price). Obtaining a monetary value for IT capital and subtracting it from tangible fixed assets is useful to avoid double-counting IT assets (as capital reported in accounting data often conflates IT and non-IT capital).

Labor (L) is measured as the number of employees obtained directly from the CITDB.

\subsubsection{Organization design and organizational learning}

Our measure of the degree of decentralization (DEC) reflects the notion that the decentralization of decision rights must be accompanied by HRM practices that endow autonomous employees with the necessary skills and incentives to make high quality decisions (Bresnahan et al. 2002, Brynjolfsson et al. 2002, Hitt and Brynjolfsson 1997). Thus, DEC is the average of 12 standardized items measuring the decentralization of decision rights and suitable HRM practices. Six items on decision rights were derived from prior studies (Bresnahan et al. 2002, Brynjolfsson and Hitt 1998, Brynjolfsson et al. 2002, Colombo et al. 2007, Hitt and Brynjolfsson 1997). Specifically, production managers were asked to indicate on a scale from 1 to 5 if the following decisions were made by managers exclusively (score 1), managers mostly, managers and workers, workers mostly or workers exclusively (score 5): The decision on (1) delivery time and priority of orders, (2) production plans, (3) distribution of work among production workers, (4) how exactly work is done, for example with regards to pace and order, (5) which machines and tools are used, and (6) coordination between different stages of the production process. Six items on HRM practices are similar to those used in previous HRM studies (Bae and Lawler 2000, Bresnahan et al. 2002, Brynjolfsson and Hitt 1998, Brynjolfsson et al. 2002, Hitt and Brynjolfsson 1997, Huselid 1995, Ichniowski et al. 1997, Osterman 1994, Sun et al. 2007). Endowing workers with decision rights is only fruitful if their work allows for a certain degree of autonomy. We thus asked production managers for two HRM practices that grant some discretion: (1) the use of (self-managed) teamwork and (2) the degree of variety of the daily work. The other HRM practices surveyed endow

\footnotetext{
7 Missing values for the percentage shares of desktop and notebook computers are imputed by using their averages in the sample.
} 
workers with the proper information, qualification, and motivation to make productive use of decision rights: (3) the amount and quality of information given to workers, (4) the amount and content of training given to them, (5) the use of pay components based on individual performance, and (6) promotion decisions based on experience and learning activities.

A firm's corporate learning type is measured by a continuous variable whose two extremes are exploration and exploitation. This reflects March's (1991) interpretation that firms have to choose between exploration and exploitation which are two ends of a continuum (Gupta et al. 2006, March 1991). The measure is the average of four standardized items related to items from other studies investigating corporate level exploration and exploitation (Auh and Mengue 2005, He and Wong 2004, Lubatkin et al. 2006). Specifically, production managers were asked to indicate on a scale from 1 to 5 if during the last five years (1) their establishment and (2) their firm as a whole have concentrated on improving existing products and processes (score 1) or on introducing new products (score 5). Further, they were asked to indicate if during the last five years (3) their establishment and (4) their firm as a whole have concentrated on existing customer groups and markets and their needs (score 1) or on developing new customer groups and markets (score 5). Given our considerations about combining a cross-section with panels described above, recall that we asked for corporate learning during the last five years. The median of the learning type measure is used to split the sample in two groups of nearly equal size for our subsample analyses. 49.7 percent of observations in the final sample represent firms with an exploratory learning type, the remaining ones firms with an exploitative learning model.

While the items for decision rights and corporate learning type were measured by classic Likert scale items rated by respondents, we used an innovative survey methodology also used by Bloom and Van Reenen (2007) to measure the items for HRM practices. Respondents were asked open questions about every HRM practice and answered freely. Their answers were then scored on scale from 1 to 5 by the interviewers. This method gives richer insights into HRM practices than standard Likert scale items. Further, as respondents do not choose from a predefined set of answers, the method mitigates the 
problem of social desirability which is important in the context of HRM practices. ${ }^{8}$ For example, some respondents might give unrealistically optimistic answers on the amount of information or training given to workers if they feel that these HRM practices are generally considered as "good". Interviewers were given prepared questions to ask. They began with general questions and continued with more specific questions based on the respondents' prior answers. Interviewers were also encouraged to deviate from the prepared questions if needed. Thus, a conversation led by the interviewer developed regarding every HRM practice. The dialogue continued until the interviewer felt that $\mathrm{s} / \mathrm{he}$ had a full picture of the HRM practice in question and could decide on a score from 1 to 5 . To facilitate scoring, the interviewers were provided with anchoring answers for the scores 1, 3, and 5. Scores 2 and 4 were used for intermediate cases. The survey instrument is in the Appendix. The interviews lasted 44.4 minutes on average which allowed for an in-depth insight into the different HRM practices. As the methodology strongly relies on the interviewers' capabilities, we undertook several steps to ensure a high interview quality. The interviewers were students of management, economics, and sociology and were selected in a two step assessment procedure from almost 80 applicants. Selection criteria were prior experience with the topics of the survey and data gathering in general as well as performance in a simulated interview situation. The interviewers were intensively trained in the survey background, methodology, questions, and software during a two day workshop that also included several simulated interviews. Interview quality was further enhanced through regular team meetings and interview monitoring by two supervisors, who listened in on 21.2 percent of all interviews and assigned scores to the respondents' answers independently from the interviewers. ${ }^{9}$ In the first week of the project, supervisors and student interviewers discussed differences between interviewer and supervisor scorings to enhance interview quality. Additionally, the supervisor scorings serve as a test of inter-rater reliability. The partial correlation coefficient (controlling for interviewer and supervisor fixed effects)

\footnotetext{
8 The Human Subjects Committee of Stanford University approved this methodology for the study of Bloom and Van Reenen (2007), because the respondents' unawareness of being scored is necessary to reduce the problem of social desirability, not risky for the respondents and their employers due to data confidentiality, and temporary as the respondents are debriefed after the end of the project.

${ }^{9}$ In our regressions, we only use interviewer scorings.
} 
of interviewer and supervisor scorings for the variable HR is 0.90 and highly significant. This suggests that the methodology gives consistent results across interviewers.

Corporate learning is measured at the establishment and firm level. However, we follow other studies and measure the degree of decentralization relating to non-managerial production workers to avoid aggregation problems (Bresnahan et al. 2002, Brynjolfsson and Hitt 1998, Brynjolfsson et al. 2002, Hitt and Brynjolfsson 1997, Osterman 1994). This group of employees is large, important, and relatively homogenous in manufacturing firms, so we are confident that DEC captures the overall degree of decentralization in the surveyed firms well (Hitt and Brynjolfsson 1997).

\subsubsection{Control variables}

To control for industry effects, we include 3-digit SIC dummies in all estimations. Where a firm's core code in ORBIS was not a manufacturing code, we replaced it by the manufacturing code from CITDB. ${ }^{10}$ The firms in the final sample come from 67 different 3-digit SIC codes or 19 different 2-digit SIC codes.

We include a dummy variable to account for the fact that ORBIS contains unconsolidated and consolidated accounting information. 79.4 percent of observations are from unconsolidated accounts.

As described above we had to extrapolate the number of computers in cases where not all firm establishments are covered by the CITDB. To control for this fact, we include the percentage of firm employees covered by the CITDB as a control variable.

We mitigate the potential for bias from combining a cross-section with panels by including a dummy variable that indicates if a firm's owner has changed in the five years before the survey, as a change in ownership often triggers major organizational change. A takeover took place in firms accounting for 15.2 percent of the observations in the final sample.

Splitting between learning types at the median of the corporate learning type measure may define firms as either explorers or exploiters even if they are relatively close to the median and thus pursue a relatively balanced learning type. To control for this, we include a dummy indicating all firms that lie

10 All firms in the sample have at least one manufacturing establishment which has been confirmed in our course of our telephone survey. It is possible that firms have not been assigned a manufacturing core code in ORBIS, because manufacturing is not the core business of a firm or because of a wrong assignment. Note that the results shown below are similar if the unadjusted core codes from ORBIS are used. 
between the 40th and the 60th percentile of the measure in all estimations. 16.4 percent of observations in the final sample represent firms with such a balanced learning type. To further mitigate potential bias from the median split procedure, we conduct another robustness test described below. ${ }^{11}$

We include a number of indicators for the quality of our survey process as control variables. To control for the representativeness of the survey, we include the percentage of firm employees employed in the surveyed establishment as a control variable. Interviewer dummies are included to control for interviewer fixed effects. Apart from potential influences on the respondents and thus the respondentrated Likert scale, differences between interviewers may lead to systematically better or worse scorings with regards to the interviewer rated items about HRM practices. Possible interviewee effects like different points of view through a different position in the firm's hierarchy or different levels of firm knowledge due to different tenure are controlled for by the respondent's tenure and the relative position in the firm's hierarchy. Interview duration is included in all analyses to control for interview quality. Finally, all estimations include year dummies and dummy variables indicating if items in the DEC or the corporate learning type measures are missing. In case of missing values, we built averages over the remaining items.

To increase interpretability and avoid multicollinearity problems that may occur in regression models with interaction terms, we mean-centered PC and DEC before computing our interaction term PC×DEC (Aiken and West 1991, Jaccard and Turrisi 2003). Descriptive statistics are given in Table 1.

\section{INSERT TABLE 1 HERE}

\section{Results}

\subsection{Baseline Regressions}

The results of our ordinary least square (OLS) estimations are given in Table 2. In the basic production function reported in column 1, the contribution of non-IT capital and labor to value added is positive

\footnotetext{
11 Note that splitting the sample in two groups enables us to obtain two sets of coefficients for different learning models, which allows us to test our hypotheses directly. Moreover, if anything, including "weak exploiters/explorers" in the respective groups biases our results against confirming our hypotheses.
} 
and significant, as expected. We further estimate the elasticity of value added for computers to be 0.167 and significant when other inputs are held constant. Our results imply decreasing returns to scale as $\beta_{1}$ $+\beta_{2}+\beta_{3}=.93<1$ (in equation (1)). Note that an $\mathrm{R}^{2}$ of 0.90 is common to production function estimations (Bresnahan et al. 2002, Brynjolfsson and Hitt 1996, Dewan et al. 2007). These basic findings hold across all other estimations in Table 2 and Table 3.

Model 1 is estimated in column 3. The interaction term $\mathrm{PC} \times \mathrm{DEC}$ is insignificant, implying that the impact of computers on firm performance is not increased by greater levels of decentralization for the full sample. Although not formally hypothesized, this corresponds to our theoretical considerations, which suggest a grouping of conflicting effects. We expect the impact of computers on firm performance to be enhanced through greater levels of decentralization only for explorers, not all firms. This appears to contradict earlier studies which found complementarities between IT and decentralization for all firms and without considering contingency factors (Bresnahan et al. 2002, Brynjolfsson et al. 2002, Hitt and Brynjolfsson 1997). An explanation may be differences in the composition of firms in these studies' and our samples. Specifically, the samples of the earlier studies cover the period from the late 1980s to the mid 1990s, when firms with greater IT investments represented early adopters of IT.12 It is intuitive to assume that these firms were also pioneers in other fields than IT, for example with regards to the adoption of modern management practices such as the decentralization of decision rights and supportive HRM practices. The combination of greater IT investments and greater decentralization may have been associated with higher firm performance for two reasons. First, the firms may have had above-average firm performance due to first-mover advantages in the adoption of these technological and organizational innovations. Second, firms with an exploratory learning type may have been prominent among early adopters of IT and decentralization as explorers tend to adopt technological and organizational innovations early. Both alternatives would have resulted in strong estimated complementarities between IT and decentralization. In the first case, the positive correlation of the ITdecentralization combination with firm performance would have resulted from first-mover advantages

12 The average number of computers per employee is 0.52 in our sample and 0.33 in Bresnahan et al. (2002). 
rather than from actual complementarities between IT and decentralization. In the second case, actual complementarities between IT and decentralization under exploration would have been measured, although the learning type was not observed. In the time period from 2000 to 2008 covered in our sample, IT is much more widespread among firms, leading to a greater variety of combinations of IT, organization design, and firm performance. Thus, positive correlations of high firm performance with specific IT-organization design combinations should indicate "real" complementarities between elements of these combinations rather than first-mover advantages. Further, complementarities can only be identified when taking into account third factors determining the actual form of complementarities for specific subgroups of firms.

The results for Hypothesis 1 are presented in column 4. As described above, the interaction term $\mathrm{PC} \times \mathrm{DEC}$ tests for complementarities between computers and decentralization for explorers, the reference group. As $\mathrm{PC} \times \mathrm{DEC}$ is positive and highly significant, our hypothesis that explorers benefit most from computers when it is coupled with decentralization is supported.

The results for Hypothesis 2 are reported in column 5. As expected, the coefficient for $\mathrm{PC} \times \mathrm{DEC}$ is negative and significantly different from zero, supporting Hypothesis 2. Under exploitation, the impact of computers on value added is smaller with greater levels of decentralization - conversely, it is greater with greater levels of centralization for exploiters.

Note that the difference between the coefficients for $\mathrm{PC} \times \mathrm{DEC}$ in columns 4 and 5 is highly significant. Thus, complementarities between computers and de/centralization are significantly different under corporate exploration and exploitation.

INSERT TABLE 2 HERE

A graphical representation of the results for corporate exploration in column 4 is given in the top panel of Figure 1. The positive and significant coefficient for the linear PC term in column 4 indicates that greater computer investments have a positive effect on value added, even for the mean value of decentralization. This is shown by the dotted line in the top part of Figure 1. However, the positive effect of greater computer investments on value added is even stronger when paired with greater levels 
of decentralization, as indicated by the positive and significant coefficient for PC $\times$ DEC in column 4 and the solid line. Moreover, the dashed line shows that for minimum levels of decentralization, i.e. maximum centralization, the effect of greater computer investments on value added is negative. This can be explained by the fact that in that case, computers facilitate and reinforce centralization, which is an unfavorable organization design for explorers. The bottom panel of Figure 1 represents the results for corporate exploitation in column 5 and can be interpreted analogously - combining computers with the "wrong" organizational form for a given learning type reduces firm performance.

\section{INSERT FIGURE 1 HERE}

\subsection{Robustness of the results}

We examine the robustness of our results to a set of alternative specifications and measures.

Theoretical and empirical research on so called skill-biased technical change argues that new technologies and higher skilled workers are complementary (Acemoglu 1998, Autor et al. 1998, Bartel and Lichtenberg 1987, Berman et al. 1998). Additionally, other work finds complementarities between organizational change and skills (Caroli and Van Reenen 2001). To mitigate the potential that our results are driven by unobserved correlations between computer use, organization design, and skills, we control for the proportion of employees in the surveyed establishments with a higher education degree. Results are presented in columns 6 and 7. All our results hold in direction and strength.

In columns 8 and 9, we measure a firm's decentralization by the decentralization of decision rights only and ignore HRM practices. The significant coefficients for $\mathrm{PC} \times \mathrm{DEC}$ suggest that our results are largely independent of alternative measures of decentralization. ${ }^{13}$

INSERT TABLE 3 HERE

\footnotetext{
13 It is not unexpected that PCxDEC loses some significance under exploration in column 8 (from 1\% to 5\%) - supporting lower-hierarchy employees with the corresponding HRM practices is essential for explorers which rely on the input by lowerlewel employees, while centralized control does not depend as much on HRM practices - explaining why PCxDEC is still negative and significant at $1 \%$ in column 9.
} 
We provide further robustness tests in Table 3. Note that most of the estimations in Table 3 do not use the full sample because of the specification or missing data.

In columns 1 and 2 of Table 3, we use the observations from the years 2003 to 2008 only. Recall that our survey asked for changes in the organizational learning model in the past five years, so theoretically firms could have changed their learning model in 2002, just before the period we cover. Using the years 2003-2008 only, we exclude the potential bias from combining a cross section on learning type with panels on computers and performance. Our results hold in direction and strength.

In columns 3 and 4 we control for the possibility that investments in computers only affect firm performance after some time. All independent variables not obtained from our survey, most notably computer investments, are instrumented by their one year lags. The results hold directionally, although the significance of the coefficients for PC $\times$ DEC under exploitation is reduced to the $5 \%$ level. The difference between both is still significant at $1 \%$.

In columns 5 and 6 we exclude firms with a relatively balanced learning type to avoid bias from classifying firms with only a slight focus on exploration (exploitation) as explorers (exploiters). To do so, we do not split the sample by the median of the learning type measure. Instead, only firms with values equal to or above the 75th percentile of the measure are denoted explorers. Firms with values equal to or below the 25th percentile are classed as exploiters. All other firms are dropped. Our results hold directionally, although $\mathrm{PC} \times \mathrm{DEC}$ in column 6 is not significant anymore.

In columns 7 and 8, we exclude all survey quality controls and missing item dummies to demonstrate that our results are largely independent of this.

To summarize, both Hypothesis 1 and Hypothesis 2 are strongly supported by a variety of different specifications and measures. There are significant complementarities between computers and decentralization for explorers, i.e. for firms who focus on developing new products and processes as a means to grow and develop. Conversely, computers and centralization are complementary for firms that focus on deepening existing product markets and improving existing processes - exploiters. 


\section{Conclusions}

In this paper, we examined the performance impact of IT in the context of organizational complements to IT. Specifically, we examined complementarities between computers and the degree of de/centralization and if they are contingent on third factors. Our analysis was guided by the information processing view of organizations, the IT and de/centralization debate and organizational learning theory. We argued that IT can facilitate both horizontal and vertical information processing, so that IT's potential can be leveraged either by greater decentralization (requiring greater horizontal information processing) or greater centralization (requiring greater vertical information processing). As both alternatives are feasible a priori, third factors may determine which of the two alternatives is more effective in a particular firm and setting. Particularly, we contend that a firm's corporate learning type determines if a decentralized or centralized organization design is appropriate so that IT and greater decentralization are complementary for firms pursuing an exploratory learning type (H1), and vice versa for an exploitative learning type (H2). We examined a unique panel dataset constructed from three independent sources and covering the years 2000 to 2008. Our hypotheses are strongly supported and our results are robust to a variety of different specifications and measures.

Our research is not without limitations. First, our measure of IT is rather narrow and does not consider all IT types such as interconnecting technologies, peripherals, and software. Although we are confident that our IT measure is sufficient to test our hypotheses, this is a constraint that could be addressed in future research. Second, we combined panel data on computers and firm performance with a cross-section on organization design and corporate learning. Although we undertook several measures to mitigate the potential bias from this, future research should aim at the use of time series data on organization design and contingency factors. Third, while our method to test for complementarities through a moderation effects model is standard in organization research, some studies have suggested alternative approaches (Burton et al. 2002; Cassiman and Veugelers 2006; Miravete and Pernías 2006; Mohnen and Röller 2005). Future studies should employ such alternatives to ensure that it actually is complementarities which explain the correlations between IT, organization 
design, and firm performance. Finally, while our sample is representative of German manufacturing firms, it would be interesting to see if our results hold up in other geographical and industry settings.

We close by discussing three central implications of our study for research and practice.

First, this paper contributes to the emerging literature on how IT can benefit different types of organizational learning (Kane and Alavi 2007) and product market strategies (Chari et al. 2008). Specifically, our results show that IT may not only directly impact organizational learning and product market strategies, but also affect it by supporting information flows in either vertically or horizontally oriented organizational structures. Future research could examine if IT and the corresponding organizational arrangements that are in place are complementary with regards to organizational learning and product market strategies in the same way that they are for firm financial performance.

Second, to the best of our knowledge, ours is the first large sample empirical study that finds evidence for a positive association between IT and centralization, thus contributing to the long-lasting IT and de/centralization debate. A particularly interesting avenue for future research in this context is to examine if different software applications are associated aiding with decentralization and centralization. For example, groupware applications might better serve horizontal information processing and thus decentralization, while decision support systems might better serve vertical information processing and thus centralization.

Finally, we believe that the most important implications for management research and practice stem from our general finding that the complementarities between IT and organization design can strongly depend on contingency factors. Future research should try to identify further contingencies that affect the complementarities between IT and organization design rather than simply test for the existence of complementarities. Subsequent studies should also examine if complements to IT other than organization design (for example, employee skills and competencies) are affected by third factors. We further believe that the inclusion of contingency factors makes the concept of complementarities more relevant to practitioners. Our findings clearly suggest that there is no such thing as a "best practice" of how to fully exploit IT's potentials for performance increases. Instead, IT is a general purpose 
technology that will only benefit firm performance if carefully aligned with both organization design and contingency factors that determine the appropriate organization design. 


\section{References}

Acemoglu, D. 1998. Why Do New Technologies Complement Skills? Directed Technical Change and Wage Inequality. Quarterly Journal of Economics 113(4) 1055-1089.

Adler, P. S., B. Goldoftas, D. Levine. 1999. Flexibility versus efficiency? A case study of model changeovers in the Toyota production system. Organization Science 10(1) 43-68.

Aiken, L. S., S. G. West. 1991. Multiple Regression: Testing and Interpreting Interactions. Sage Publications, Newbury Park, CA.

Anand, K. S., H. Mendelson. 1997. Information and Organization for Horizontal Multimarket Coordination. Management Science 43(12) 1609-1627.

Ancona, D. G., P. S. Goodman, B. S. Lawrence, M. L. Tushman. 2001. Time: A New Research Lens. Academy of Management Review 26(4) 645-663.

Anderson, M. C., R. D. Banker, S. Ravindran. 2006. Value implications of investments in information technology. Management Science 52(9) 1359-1376.

Aoki, M. 1986. Horizontal vs. Vertical Information Structure of the Firm. American Economic Review 76(5) 971-983.

Aral, S., P. Weill. 2007. IT Assets, Organizational Capabilities, and Firm Performance: How Resource Allocations and Organizational Differences Explain Performance Variation. Organization Science 18(5) 763-780.

Athey, S., S. Stern. 2003. An empirical framework for testing theories about complementarity in organizational design. Working Paper, NBER, Cambridge, MA.

Auh, S., B. Mengue. 2005. Balancing Exploration and Exploitation: The Moderating Role of Competitive Intensity. Journal of Business Research 58 1652-1661.

Autor, D. H., L. F. Katz, A. B. Krueger. 1998. Computing Inequality: Have Computers Changed the Labor Market?. Quarterly Journal of Economics 113(4) 1169-1213.

Bae, J., J. J. Lawler. 2000. Organizational and HRM strategies in Korea: impact on firm performance in an emerging economy. Academy of Management Journal 43(3) 502-517.

Bartel, A. P., F. R. Lichtenberg. 1987. The Comparative Advantage of Educated Workers in Implementing New Technology. Review of Economics and Statistics 69 1-11.

Benner, M. J., M. L. Tushman. 2003. Exploitation, Exploration, and Process Management: The Productivity Dilemma Revisited. Academy of Management Review 28(2) 238-256.

Berman, E., J. Bound, S. Machin. 1998. Implications of Skill-Biased Technological Change: International Evidence. Quarterly Journal of Economics 113(4) 1245-1279.

Bertschek, I., U. Kaiser 2004. Productivity Effects of Organizational Change: Microeconometric Evidence. Management Science 50(3) 394-404.

Bharadwaj, A. S., S. G. Bharadwaj, B. R. Konsynski. 1999. Information technology effects on firm performance as measured by Tobin's q. Management Science 45(7) 1008-1024.

Bloom, N., L. Garicano, R. Sadun, J. Van Reenen. 2009. The distinct effects of Information and Communication Technology on firm organization. Working Paper, NBER, Cambridge, MA.

Bloom, N., J. Van Reenen. 2007. Measuring and explaining management practices across firms and countries. Quarterly Journal of Economics 122(4) 1351-1408.

Bolton, P., M. Dewatripont. 1994. The firm as a communication network. Quarterly Journal of Economics 109(4) 809-839.

Bresnahan, T., E. Brynjolfsson, L. Hitt. 2002. Information Technology, Workplace Organization, and the Demand for Skilled Labor: Firm level Evidence. Quarterly Journal of Economics 117(1) 339-376.

Bresnahan, T., M. Trajtenberg. 1995. General purpose technologies 'Engines of growth'?. Journal of Econometrics 65(1) 83-108. 
Brown, S. L., K. M. Eisenhardt. 1998. Competingon the Edge: Strategy as Structured Chaos. Harvard Business School Press, Boston, MA.

Brynjolfsson, E. 1993. The productivity paradox of information technology. Communications of the ACM 36(12) 66-77.

Brynjolfsson, E. 1994. Information Assets, Technology, and Organization. Management Science 40(12) 1645-1662.

Brynjolfsson, E., L. Hitt. 1995. Information Technolny as a Factor of Production: The Role of Differences Among Firms. Economics of Innovation and New Technology 3(3) 183-199.

Brynjolfsson, E., L. Hitt. 1996. Paradox Lost? Firm-Level Evidence on the Returns to Information Systems Spending. Management Science 42(4) 541-558.

Brynjolfsson, E., L. Hitt. 1998. Information Technology and Organizational Design: Evidence from Micro Data. Working Paper, MIT Sloan School, Cambridge, MA.

Brynjolfsson, E., L. Hitt. 2000. Beyond Computation: Information Technology, Organizational Transformation and Business Performance. Journal of Economic Perspectives 14(4) 23-48.

Brynjolfsson, E., L. Hitt, S. Yang. 2002. Intangible Assets: Computers and Organizational Capital. Brookings Papers on Economic Activity 1 137-199.

Brynjolfsson, E., T. W. Malone, V. Gurbaxani, A. Kambil. 1994. Does Information Technology Lead to Smaller Firms?. Management Science 40(12) 1628-1644.

Brynjolfsson, E., H. Mendelson. 1993. Information Systems and the Organization of Modern Enterprise. Journal of Organizational Computing and Electronic Commerce 3(3) 245-255.

Brynjolfsson, E., S. Yang. 1996. Information Technology and Productivity: A Review of the Literature. Advances in Computers 43 179-214.

Burns, T., G. M. Stalker. 1961. The Management of Innovation. Tavistock, London, UK.

Burton, R. M., J. Lauridsen, B. Obel. 2002. Return on Assets Loss from Situational and Contingency Misfits. Management Science 48(11) 1461-1485.

Caroli, E., J. Van Reenen. 2001. Skill-Biased Organizational Change? Evidence from a Panel of British and French Establishments. Quarterly Journal of Economics 116(4) 1449-1492.

Cassiman, B., R. Veugelers. 2006. In Search of Complementarity in Innovation Strategy: Internal RandD and External Knowledge Acquisition. Management Science 52(1) 68-82.

Chan, Y. E. 2000. IT Value: The Great Divide Between Qualitative and Quantitative and Individual and Organizational Measures. Journal of Management Information Systems 16(4) 225-261.

Chari M. D. R., S. Devaraj, P. David. 2008. Research Note: The Impact of IT Investments and Diversification Strategies. Management Science 54(1) 224-234.

Chow, G. C. 1960. Tests of Equality Between Sets of Coefficients in Two Linear Regressions. Econometrica 28(3) 591-605.

Clemons, E. K., M. C. Row. 1991. Sustaining IT advantage: The role of structural differences. MIS Quarterly. 15(3) 275-292.

Colombo, M. G., M. Delmastro, L. Rabbiosi. 2007. "High performance" work practices, decentralization, and profitability: evidence from panel data. Industrial and Corporate Change 16(6) 1037-1067.

Crespi, G., C. Criscuolo. 2006. Information Technology, Organisational Change and Productivity Growth: Evidence from UK Firms. Working Paper, CEP, LSE, London, UK.

Draft, R. L., R. H. Lengel. 1986. Organizational Information Requirements, Media Richness and Structural Design. Management Science 32(5) 554-571.

David, P. A. 1990. The Dynamo and the Computer: An Historical Perspective on the Modern Productivity Paradox. The American Economic Review 80(2) 355-361.

David, P. A., G. Wright. 1999. General-purpose technologies and surges in productivity: Historical reflections on the future of the ICT revolution. Working Paper, University of Oxford, Oxford, UK. 
Dewan, S., K. L. Kraemer. 2000. Information Technology and Productivity. Evidence from Country-Level Data. Management Science 46(4) 548-562.

Dewan, S., S. C. Michael, C. Min. 1998. Firm characteristics and investments in information technology: Scale and scope effects. Information Systems Research 9(3) 219-232.

Dewan, S., S. Charles, V. Gurbaxani. 2007. Investigating the Risk-Return Relationship of Information Technology Investment: Firm-Level Empirical Analysis. Management Science 53(12) 1829-1842.

Dewett, T. G. R. Jones. 2001. The role of information technology in the organization: a review, model, and assessment. Journal of Management 27(3) 313-346.

Diamantopoulos, A., P. Riefler, K. P. Roth. 2008. Advancing formative measurement models. Journal of Business Research 61(12) 1203-1218.

Duncan, R.B. 1976. The ambidextrous organization: Designing dual structures for innovation. R. H. Kilmann, L. R. Pondy, D. P. Slevin, eds. The Management of Organization Design. Elsevier, NY.

Galbraith, J. R. 1973. Designing Complex Organizations. Addison-Wesley, Reading, MA.

Galbraith, J. R. 1974. Organization Design: An Information Processing View. Interfaces 4(5) 28-36.

Galbraith, J. R. 1977. Organization design. Addison-Wesley, Reading, MA.

George, J. F., J. L. King. 1991. Examining the computing and centralization debate. Communications of the ACM 34(7) 62-72.

Ghemawat, P., J. E. Ricart i Costa. 1993. The organizational tension between static and dynamic efficiency. Strategic Management Journal 14(Winter Special Issue) 59-73.

Gibson, C., J. Birkinshaw. 2004. The antecedents, consequences, and mediating role of organizational ambidexterity. Academy of Management Journal 47(2) 209-226

Greene, W. H. 2008. Econometric Analysis. Pearson Education, London, UK.

Gupta, A. K., K. G. Smith, C. E. Shalley. 2006. The Interplay Between Exploration and Exploitation. Academy of Management Journal 49(4) 693-706.

Gurbaxani, V., S. Whang. 1991. The Impact of Information Systems on Organizations and Markets. Communications of the ACM 34(1) 59-73.

Hannan, M. T., J. H. Freeman. 1984. Structural inertia and organizational change. American Sociological Review 49 149-164.

Hayek, F. A. 1945. The use of knowledge in society. The American Economic Review 35(4) 519-530.

He, Z.-L., P.-K. Wong. 2004. Exploration vs. exploitation: An empirical test of the ambidexterity hypothesis. Organization Science 15(4) 481-531.

Hitt, L., E. Brynjolfsson. 1997. Information technology and internal firm organization: an exploratory analysis. Journal of Management Information Systems 14(2) 81-101.

Holmqvist, M. 2004. Experiential learning processes of exploration and exploitation within and between organizations: An empirical study of product development. Organization Science 15(1) 70-81.

Huber, G. P. 1990. A Theory of the Effects of Advanced Information Technologies on Organizational Design, Intelligence, and Decision Making. Academy of Management Review 15(1) 47-71.

Huselid, M. A. 1995. The Impact of Human Resource Management Practices on Turnover, Productivity, and Corporate Financial Performance. Academy of Management Journal 38(3) 635-672.

Ichniowski, C., K. Shaw, G. Prennushi. 1997. The Effects of Human Resource Management Practices on Productivity: A Study of Steel Finishing Lines. The American Economic Review 87(3) 291-313.

Jaccard, J. J., R. Turrisi. 2003. Interaction Effects in Multiple Regression. Sage, Thousand Oaks, CA.

Jarvis, C. B., S. B. MacKenzie, P. M. Podsakoff. 2003. A Critical Review of Construct Indicators and Measurement Model Misspecification in Marketing and Consumer Research. Journal of Consumer Research 30(2) 199-218.

Kane, G. C., M. Alavi. 2007. Information Technology and Organizational Learning: An Investigation of Exploration and Exploitation Process. Organization Science 18(5) 796-812. 
Kock, N. 2004. The Psychobiological Model: Towards a New Theory of Computer-Mediated Communication Based on Darwinian Evolution. Organization Science 15(3) 327-348.

Kyriakopoulos, K., C. Moorman. 2004. Tradeoffs between marketing exploitation and exploration strategies: The overlooked role of market orientation. International Journal of Research in Marketing 21(3) 219-240.

Leavitt, H. J., T. L. Whistler 1958. Management in the 1980s. Harvard Business Review NovemberDecember 41-48.

Lee, S. L. 1994. Electronic Mail as a Medium for Rich Communication: An Empirical Investigation Using Hermeneutic Interpretation. MIS Quarterly 18(2) 143-157.

Lewin, A. Y., C. P. Long, T. N. Carroll. 1999. The coevolution of new organizational forms. Organization Science 10(5) 535-550.

Loveman, G. W. 1994. An Assessment of the Productivity Impact of Information Technologies. T.J. Allen, S. M. S. Morton, eds. Information Technology and the Corporation of the 1990s: Research Studies. Oxford University Press, Oxford, UK.

Lubatkin, M. H., Z. Simsek, Z., Y. Ling, J. F. Veiga. 2006. Ambidexterity and Performance in Small-to Medium-Sized Firms: The Pivotal Role of Top Management Team Behavioral Integration. Journal of Management 32(5) 646-672.

March, J. 1991. Exploration and exploitation in organizational learning. Organization Science 2(1) 71-87.

Markus, M. L. 1994. Electronic Mail As the Medium of Managerial Choice. Organization Science 5(2) 502527.

Mata, F. J., W. L. Fuerst, J. B. Barney. 1995. Information Technology and Sustained Competitive Advantage: A Resource-Based Analysis. MIS Quarterly 19(4) 487-505.

Miles, R., C. C. Snow. 1978. Organizational strategy, structure, and process. McGraw-Hill Book Co., NY.

Miller, D., P. H. Friesen. 1985. A Longitudinal Study of the Corporate Life Cycle. Management Science 30(10) 1161-1183.

Miravete, E. J., J. C. Pernías. 2006. Innovation complementarity and scale of production. Journal of Industrial Economics 54(1) 1-29.

Mohnen, P., L.-H. Röller. 2005. Complementarities in innovation policy. European Economic Review 49(6) 131-1450.

Mukhopadhyay, T., S. Rajiv, K. Srinivasan. 1997. Information technology impact on process output and quality. Management Science 43(12) 1645-1659.

Nault, B. R. 1998. Information Technology and Organization Design: Locating Decisions and Information. Management Science 44(10) 1321-1335.

Osterman, P. 1994. How Common is Workplace Transformation and Who Adopts it? Industrial and Labor Relations Review 47(2) 173-188.

Pinsonneault, A., K. L. Kraemer. 1997. Middle Management Downsizing: An Empirical Investigation of the Impact of Information Technology. Management Science 43(5) 659-679.

Podsakoff, P. M., S. B. MacKenzie, N. P. Podsakoff. 2003. Common Method Biases in Behavioral Research: A Critical Review of the Literature and Recommended Remedies. Journal of Applied Psychology 88(5) 879-903.

Porter, M. E. 1985. Competitive Advantage. Free Press, New York.

Powell, T. C., A. Dent-Micallef. 1997. Information Technology as Competitive Advantage: The Role of Human, Business, and Technology Resources. Strategic Management Journal 18(5) 375-405.

Radner, R. 1993. The Organization of Decentralized Information Processing. Econometrica 61(5) 11091146.

Roach, S. S. 1987. America's Technology Dilemma: A Profile of the Information Economy. Special Economic Study, Morgan Stanley, New York. 
Roberts, J. 2007. The modern firm: Organizational design for performance and growth. Oxford University Press, NY.

Robey, D. 1977. Computers and Management Structure: Some Empirical Findings Re-examined. Human Relations 30(1) 963-976.

Sabherwal, R., A. Jeyaraj, C. Chowa. 2006. Information System Success: Individual and Organizational Determinants. Management Science 52(12) 1849-1864.

Shim, J. P., M. Warkentin, J. F. Courtney, D. J. Power, R. Sharda, C. Carlsson. 2002. Past, present, and future of decision support technology. Decision Support Systems 33(2) 111-126.

Solow, R. 1987. We'd Better Watch out. New York Times Book Review (July 12), 36.

Stieglitz, N., K. Heine. 2007. Innovations and the role of complementarities in a strategic theory of the firm. Strategic Management Journal 28(1) 1-15.

Sun, L.-Y., S. Aryee, Samuel, K. S. Law. 2007. High-Performance human resource practices, citizenship behavior, and organizational performance: A relational perspective. Academy of Management Journal 50(3) 558-577.

Tushman, M. L., D. A. Nadler. 1978. Information Processing as an Integration Concept in Organizational Design. Academy of Management Review 3(3) 613-624.

Tushman, M. L., C. O’Reilly. 1996. Ambidextrous organizations: Managing evolutionary and revolutionary change. California Management Review 38 8-30.

Uotila, J., M. Maula, T. Keil, S. A. Zahra. 2009. Exploration, exploitation, and financial performance: analysis of S\&P 500 corporations. Strategic Management Journal 30(2) 221-231.

Weill, P., S. Aral. 2006. Generating premium returns on your IT investments. Sloan Management Review 47(2) 39-48.

Wooldridge, J. M. 2009. Introductory Econometrics. Thomson South-Western, Mason, Australia.

Wyner, G. M., T. W. Malone. 1996. Cowboys or Commanders: Does Information Technology Lead to Decentralization. Proceedings of the International Conference on Information Systems, Columbus, $\mathrm{OH}$.

Zammuto, R. F., T. L. Griffith, A. Majchrzak, D. J. Dougherty, S. Faraj. 2007. Information Technology and the Changing Fabric of Organization. Organization Science 18(5) 749-762. 


\section{Appendix. Survey items for HRM practices variable (HR)}

\section{(1) Intensity of (self-managed) teamwork}

\section{Prepared questions}

- Could you describe the tasks that worker teams fulfill?

- Is teamwork used routinely or irregularly?

- How much discretion do teams have in their daily work?

- Which role do managers play for worker teams?

\begin{tabular}{|l|l|l|}
\hline Example answer for score 1 & Example answer for score 3 & Example answer for score 5
\end{tabular}

Teams are used irregularly or if Teams are used routinely. The Teams are used routinely. The required only. teams have no discretion. Their teams are self-managed. work is regulated by managers Managers rather play a or by other means. supportive role.

\section{(2) Variety of daily work}

\section{Prepared questions}

- Could you describe for how many different tasks a worker usually qualifies?

- To what extent do these tasks differ from each other?

- For what reasons do workers rotate between these tasks?

- How often do workers switch between these tasks?

\begin{tabular}{|l|l|l|}
\hline Example answer for score 1 & Example answer for score 3 & Example answer for score 5 \\
\hline Workers are qualified for one & $\begin{array}{l}\text { Workers are qualified for } \\
\text { tlightly different tasks within } \\
\text { one step of the production } \\
\text { process. They switch between } \\
\text { these tasks from time to time } \\
\text { or if required. }\end{array}$ & $\begin{array}{l}\text { Workers are qualified for } \\
\text { clearly different tasks and } \\
\text { switch between them in regular } \\
\text { time intervals. }\end{array}$ \\
\hline
\end{tabular}

\section{(3) Amount and quality of information}

\section{Prepared questions}

- For which topics do you make sure that information is always provided for workers?

- Why should workers be informed on these topics?

- How do workers receive this information?

- How often do workers receive this information?

\begin{tabular}{|l|l|l|}
\hline Example answer for score 1 & Example answer for score 3 & Example answer for score 5
\end{tabular}

Workers do not receive $\quad$ Worker receive information $\quad$ In addition to what is described
information from the firm or the firm does not actively, regularly and/or in a well actively, regularly and in a well in score 3, workers actively, accessible way. The information are needed for the accessible way inform workers. functioning of the workers' own job (for example quantity and quality produced in the regularly and accessibly receive information on other sections of the establishment or firm to be able to coordinate with own production step). these sections. 


\section{(4) Training intensity and variety}

\section{Prepared questions}

- Could you describe the training programs that are provided for workers?

- What are the contents of these training programs?

- What are the goals of these training programs?

- How often do these training programs take place?

\section{Example answer for score $1 \quad$ Example answer for score 3 Example answer for score 5}

Workers do not participate in Workers participate in regular Workers participate in regular regular training programs which upgrade/expand their capabilities. No trainings or only trainings mandatory by law (for example job safety) training programs which are directed on upgrading/ training programs which are expanding existing capabilities that are needed for the workers' own job. in addition to what is described in score 3 - directed on acquiring additional capabilities from other areas or take place. general capabilities like leadership capabilities or „soft skills".

\section{(5) Performance review and pay}

\section{Prepared questions}

- Could you describe how the workers' individual performance

(or the performance of their workspace/team) is reviewed?

- How often do the performance reviews take place?

- Which consequences do the performance reviews have on the workers' pay?

\begin{tabular}{|l|l|l|}
\hline Example answer for score 1 & Example answer for score 3 & Example answer for score 5 \\
\hline $\begin{array}{l}\text { Individual/workspace/team } \\
\text { performance is not reviewed } \\
\text { regularly. Workers receive a } \\
\text { fixed pay. }\end{array}$ & $\begin{array}{l}\text { Individual/workspace/team } \\
\text { performance is reviewed } \\
\text { regularly. Performance reviews } \\
\text { do not impact pay. }\end{array}$ & $\begin{array}{l}\text { Individual/workspace/team } \\
\text { performance is reviewed } \\
\text { regularly. Performance reviews } \\
\text { strongly impact pay. }\end{array}$ \\
\hline
\end{tabular}

\section{(6) Promotion criteria}

\section{Prepared questions}

- Imagine that a higher position is free and that one of two candidates for the position is working for your company five more years than the other candidate. Who will be promoted?

- Aside from leadership skills: Which kind of knowledge and background is needed for positions on higher hierarchical levels in your company?

\begin{tabular}{|l|l|l|}
\hline Example answer for score 1 & Example answer for score 3 & Example answer for score 5 \\
\hline $\begin{array}{l}\text { Employees are exclusively } \\
\text { promoted on the basis of } \\
\text { tenure/age. }\end{array}$ & $\begin{array}{l}\text { Employees are promoted on } \\
\text { the basis of special knowledge } \\
\text { and experience in the area they } \\
\text { are promoted to. }\end{array}$ & $\begin{array}{l}\text { Employees are mainly } \\
\text { promoted on the basis of } \\
\text { heterogeneous knowledge and } \\
\text { experiences (for example } \\
\text { different areas of expertise, } \\
\text { departments, functions, } \\
\text { establishments, etc.). }\end{array}$ \\
\hline
\end{tabular}


Figure 1. Information technology, de/centralization, and firm performance under corporate exploration (top) and corporate exploitation (bottom)
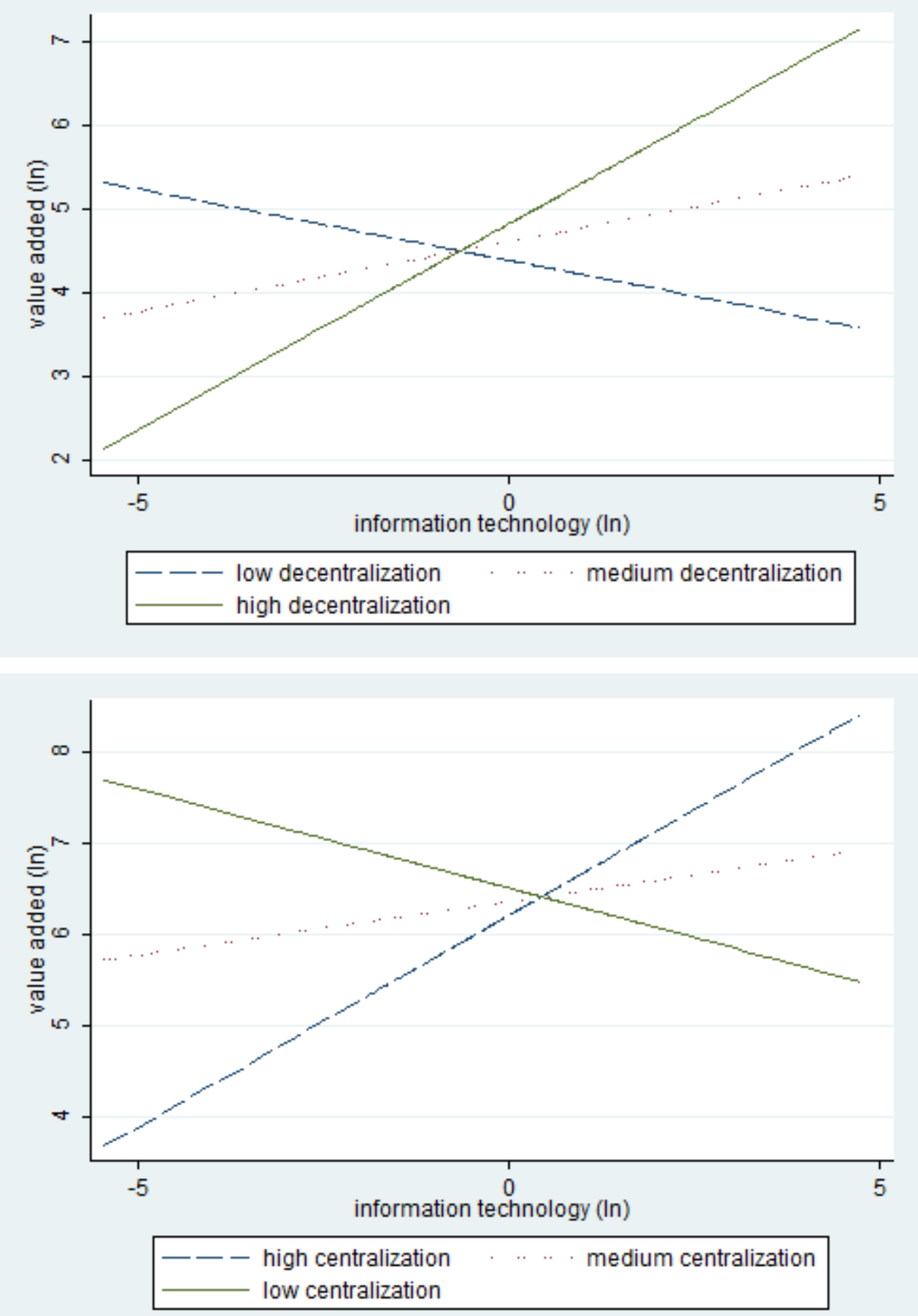
Table 1. Descriptive statistics

\begin{tabular}{|c|c|c|c|c|c|c|}
\hline Description & Variable & Obs. & Mean & Std. dev. & Min. & Max. \\
\hline Value added * & $\operatorname{Ln}(\mathrm{VA})$ & 572 & 10.6758 & 1.2157 & 7.9266 & 15.5199 \\
\hline \multicolumn{2}{|c|}{ Number of computers ${ }^{\circ} \operatorname{Ln}(\mathrm{PC})$} & 572 & 5.4175 & 1.3437 & 0.0000 & 10.1928 \\
\hline Capital * & $\operatorname{Ln}(\mathrm{C})$ & 572 & 9.3223 & 1.7389 & 3.4243 & 15.5852 \\
\hline Labor $^{\circ}$ & $\operatorname{Ln}(\mathrm{L})$ & 572 & 6.2577 & 1.1194 & 4.0943 & 10.4341 \\
\hline Decentralization \# & DEC & 572 & 0.0328 & 0.4465 & -1.2839 & 1.3002 \\
\hline $\begin{array}{l}\% \text { employees } \\
\text { with degree \# }\end{array}$ & $\operatorname{Ln}(\mathrm{DEG})$ & 572 & 2.2254 & 0.9227 & 0.0000 & 4.3820 \\
\hline \multicolumn{2}{|c|}{$\%$ of employees covered by the CITDB ${ }^{\circ}$} & 572 & 0.8231 & 0.2665 & 0.0132 & 1.0000 \\
\hline \multicolumn{2}{|c|}{$\begin{array}{l}\% \text { of employees covered } \\
\text { by author's survey }{ }^{\circ / \#}\end{array}$} & 572 & 0.6995 & 0.3021 & 0.0163 & 1.0000 \\
\hline \multicolumn{2}{|c|}{ Tenure of respondent (years) \# } & 572 & 15.9476 & 10.6932 & 1.0000 & 46.0000 \\
\hline \multicolumn{2}{|c|}{$\begin{array}{l}\text { Relative hierarchical level of respondent } \\
\text { (counted from bottom of hierarchy) \# }\end{array}$} & 572 & 0.7093 & 0.1201 & 0.3333 & 1.0000 \\
\hline \multicolumn{2}{|c|}{ Interview duration (minutes) $\#$} & 572 & 44.4423 & 9.0956 & 26.0000 & 78.0000 \\
\hline
\end{tabular}

Source: * ORBIS, ${ }^{\circ}$ CITDB, \# authors' survey; value added, IT capital, and non-IT capital in thousand Euros; value added, number of computers, capital, and labor in natural logarithms 
Table 2. Main estimations and first robustness tests

\begin{tabular}{|c|c|c|c|c|c|c|c|c|c|c|c|c|}
\hline & (1) & (2) & (3) & (4) & (5) & \multirow{3}{*}{$\begin{array}{c}\text { Difference } \\
\text { (4) \& (5) } \\
\text { significant? }\end{array}$} & (6) & (7) & \multirow{3}{*}{$\begin{array}{l}\text { Difference } \\
\text { (6) \& (7) } \\
\text { significant? }\end{array}$} & (8) & (9) & \multirow{3}{*}{$\begin{array}{c}\text { Difference } \\
\text { (8) \& (9) } \\
\text { significant? }\end{array}$} \\
\hline Sample & Full sample & Full sample & Full sample & Explorers & Exploiters & & Explorers & Exploiters & & Explorers & Exploiters & \\
\hline Robustness test & - & - & & - & - & & \multicolumn{2}{|c|}{ Employee skills } & & \multicolumn{2}{|c|}{ Decision rights only } & \\
\hline $\ln (\mathrm{PC})$ & $0.1670^{* * *}$ & $0.1295^{* * *}$ & $0.1304^{* * *}$ & $0.1667^{* * *}$ & $0.1170^{*}$ & & $0.1622^{* * *}$ & 0.1128 & & $0.1645^{* * *}$ & 0.1102 & \\
\hline Number of computers & $(0.038)$ & $(0.035)$ & $(0.035)$ & $(0.050)$ & $(0.067)$ & & $(0.050)$ & $(0.069)$ & & $(0.051)$ & $(0.069)$ & \\
\hline $\ln (C)$ & $0.2316^{* * *}$ & $0.2367^{* * *}$ & $0.2367^{* * *}$ & $0.2721^{* * *}$ & $0.2810^{* * *}$ & & $0.2708^{* * *}$ & $0.2850^{* * *}$ & & $0.2570^{* * *}$ & $0.2863^{* * *}$ & \\
\hline Non-IT capital & $(0.039)$ & $(0.039)$ & $(0.039)$ & $(0.059)$ & $(0.074)$ & & $(0.060)$ & $(0.075)$ & & $(0.059)$ & $(0.071)$ & \\
\hline $\ln (L)$ & $0.5359^{* * *}$ & $0.5888^{* * *}$ & $0.5932^{* * *}$ & $0.4606^{* * *}$ & $0.4752^{* * *}$ & & $0.4655^{* * *}$ & $0.4536^{* * *}$ & & $0.5021^{* * *}$ & $0.5194^{* * *}$ & \\
\hline Labor & $(0.075)$ & $(0.071)$ & $(0.069)$ & $(0.089)$ & $(0.116)$ & & $(0.089)$ & $(0.123)$ & & $(0.087)$ & (0.117) & \\
\hline DEC & & 0.1147 & 0.1256 & 0.1215 & $0.3168^{*}$ & & 0.1124 & $0.3126^{*}$ & & $0.2609^{* *}$ & $0.2698^{* *}$ & \\
\hline Decentralization & & $(0.090)$ & $(0.089)$ & $(0.127)$ & $(0.180)$ & & $(0.132)$ & $(0.177)$ & & $(0.104)$ & $(0.123)$ & \\
\hline $\ln (P C) \times D E C$ & & & $\begin{array}{l}-0.0346 \\
(0.065)\end{array}$ & $\begin{array}{c}0.2564^{* * *} \\
(0.060)\end{array}$ & $\begin{array}{c}-0.2629 * * * \\
(0.081)\end{array}$ & Yes*** & $\begin{array}{c}0.2646^{* * *} \\
(0.066)\end{array}$ & $\begin{array}{l}-0.2568^{* * *} \\
(0.082)\end{array}$ & Yes*** & $\begin{array}{c}0.1388^{* *} \\
(0.054)\end{array}$ & $\begin{array}{c}-0.2584 * * * \\
(0.071)\end{array}$ & Yes*** \\
\hline $\begin{array}{l}\ln (\mathbf{D E G}) \\
\% \text { of employees with degree }\end{array}$ & & & & & & & $\begin{array}{l}0.0406 \\
(0.079)\end{array}$ & $\begin{array}{l}0.1047 \\
(0.087)\end{array}$ & & & & \\
\hline Observations & 572 & 572 & 572 & 284 & 288 & & 284 & 288 & & 284 & 288 & \\
\hline Firms & 182 & 182 & 182 & 95 & 87 & & 95 & 87 & & 95 & 87 & \\
\hline $\mathbf{R}^{2}$ & 0.90 & 0.91 & 0.91 & 0.97 & 0.92 & & 0.97 & 0.92 & & 0.97 & 0.92 & \\
\hline
\end{tabular}

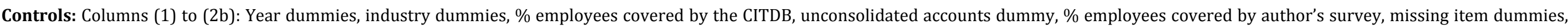
interviewer dummies, interview duration, respondent's tenure, respondent's relative hierarchical position, recent change of ownership, mixed learning type dummy.

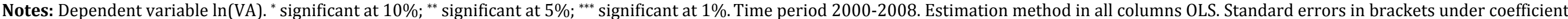
clustered by firm, that is Huber-White robust to heteroskedasticity and autocorrelation of unknown form. Chow test used to test for significant differences between columns. 
Table 3. Further robustness tests

\begin{tabular}{|c|c|c|c|c|c|c|c|c|c|c|c|c|}
\hline \multirow{3}{*}{$\begin{array}{l}\text { Sample } \\
\text { Robustness test }\end{array}$} & (1) & (2) & \multirow{3}{*}{$\begin{array}{c}\text { Difference } \\
\text { (1) \& (2) } \\
\text { significant? }\end{array}$} & (3) & (4) & \multirow{4}{*}{$\begin{array}{c}\text { Difference } \\
\text { (3) \& (4) } \\
\text { significant? }\end{array}$} & (5) & (6) & \multirow{3}{*}{$\begin{array}{c}\text { Difference } \\
\text { (5) \& (6) } \\
\text { significant? }\end{array}$} & (7) & (8) & \multirow{3}{*}{$\begin{array}{c}\text { Difference } \\
\text { (7) \& (8) } \\
\text { significant? }\end{array}$} \\
\hline & Explorers & Exploiters & & Explorers & Exploiters & & Explorers & Exploiters & & Explorers & Exploiters & \\
\hline & \multicolumn{2}{|c|}{$2003-2008$ only } & & \multicolumn{2}{|c|}{ Lagged independent var. } & & \multicolumn{2}{|c|}{ Stricter sample split } & & \multicolumn{2}{|c|}{ No interviewer controls } & \\
\hline $\ln (\mathrm{PC})$ & $0.1511^{* *}$ & 0.1297 & & $0.1781^{* * *}$ & 0.0475 & & 0.0832 & 0.2043 & & $0.1623^{* * *}$ & $0.1524^{* *}$ & \\
\hline Number of computers & $(0.064)$ & $(0.085)$ & & $(0.061)$ & $(0.077)$ & & $(0.087)$ & $(0.130)$ & & $(0.059)$ & $(0.068)$ & \\
\hline $\ln (C)$ & $0.2537^{* * *}$ & $0.2564^{* * *}$ & & $0.3062^{* * *}$ & $0.3355^{* * *}$ & & $0.2081^{*}$ & $0.5522^{* * *}$ & & $0.3012^{* * *}$ & $0.2631^{* * *}$ & \\
\hline Non-IT capital & $(0.078)$ & $(0.078)$ & & $(0.058)$ & $(0.083)$ & & $(0.103)$ & $(0.179)$ & & $(0.056)$ & $(0.078)$ & \\
\hline $\ln (\mathrm{L})$ & $0.4692^{* * *}$ & $0.4702^{* * *}$ & & $0.4307^{* * *}$ & $0.5035^{* * *}$ & & 0.1946 & -0.0101 & & $0.3958^{* * *}$ & $0.3768^{* * *}$ & \\
\hline Labor & (0.119) & $(0.125)$ & & $(0.096)$ & $(0.120)$ & & $(0.183)$ & $(0.187)$ & & (0.103) & $(0.112)$ & \\
\hline DEC & 0.1424 & $0.3511^{*}$ & & 0.1791 & $0.3597^{*}$ & & -0.4146 & $1.5575^{* *}$ & & 0.0320 & 0.2118 & \\
\hline Decentralization & $(0.146)$ & $(0.195)$ & & $(0.127)$ & $(0.184)$ & & $(0.274)$ & $(0.738)$ & & $(0.140)$ & $(0.154)$ & \\
\hline $\ln (P C) \times D E C$ & $\begin{array}{c}0.2769 * * * \\
(0.086)\end{array}$ & $\begin{array}{c}-0.2638^{* * *} \\
(0.082)\end{array}$ & Yes*** & $\begin{array}{c}0.2455^{* * *} \\
(0.067)\end{array}$ & $\begin{array}{c}-0.2260^{* *} \\
(0.089)\end{array}$ & Yes*** & $\begin{array}{c}0.7069 * * * \\
(0.182)\end{array}$ & $\begin{array}{r}-0.2100 \\
(0.177)\end{array}$ & Yes*** & $\begin{array}{c}0.2387^{* * *} \\
(0.072)\end{array}$ & $\begin{array}{c}-0.1813^{*} \\
(0.101)\end{array}$ & Yes $^{* * *}$ \\
\hline Observations & 203 & 219 & & 236 & 243 & & 141 & 156 & & 284 & 288 & \\
\hline Firms & 91 & 86 & & 84 & 82 & & 46 & 45 & & 95 & 87 & \\
\hline $\mathbf{R}^{2}$ & 0.95 & 0.94 & & 0.95 & 0.93 & & 0.99 & 0.91 & & 0.95 & 0.90 & \\
\hline
\end{tabular}

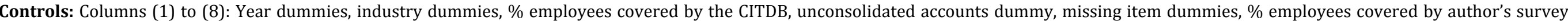

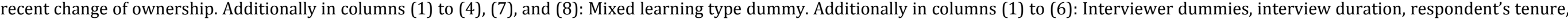
respondent's relative hierarchical position.

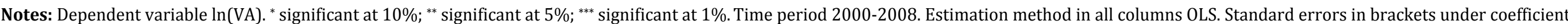
clustered by firm, that is Huber-White robust to heteroskedasticity and autocorrelation of unknown form. Chow test used to test for significant differences between columns. 